\title{
A House is a Figure between the Earth and the Sky Case Study: Batak Toba House in Samosir Island
}

\author{
Himasari Hanan \\ Department of Architecture, School of Architecture, Planning and Policy Development, \\ Institut Teknologi Bandung, Indonesia \\ hanan@ar.itb.ac.id
}

\begin{abstract}
Vernacular architecture is not simply determined externally by the natural forces of its physical context. The poetic expression of Batak Toba house must have involved creative imagination in the mind of the people that may reflect the structure of mental models that constitute the thinking. This paper is intended to explore the presence of "generative concepts" of building's form and its architecture, which is based on the figuration of relationship between man and the nature. Three Batak Toba settlements in Samosir island are selected for the analysis of the archetypes in Batak architecture in the attempt to und erstand the existential basis of architecture.
\end{abstract}

Keywords: archetype, anthropomorphic, house on stilts, Batak Toba

\section{Introduction}

To Batak people architecture of the house and arrangement of houses in a settlement reflect, materialize and eternalize ideas and images of the ideal life of the people. The buildings grow naturally into being part of the form and history of its physical context. The house embraces qualities which bring about a meaningful dialogue with the existing situation. The architecture gives physical form to the ideas and hopes of the people, and it shapes also the relations between people in the community. Batak people see everyday life consists of concrete things, and buildings are there to represent the comprehensive world of everyday life. The architecture transforms people's ideas into concrete things in order that people can see them. The architecture of the house thereafter created to articulate the experience of man being in the world and to strengthen the sense of reality and being oneself. Instead of creating mere objects of visual seduction, the architecture relates, mediates and projects meanings.

A Batak Toba settlement is originally set up by related people belong to a certain family clan in proximity to agriculture land as food resources. The settlement is the most important basic unit of economic and social life. A perimeter wall is built around a settlement to protect the people from the outside world of uncontrolled spiritual forces. Therefore images of guardian spirits are usually placed at the entrance gate of the settlement. Houses are built within the perimeter wall on stilts that have been set directly into the ground or rest upon flat foundation stones. The foundation stones allow the house to move in flexibility during earthquake and protect the house from termites.

A Batak Toba house has a post and lintel wooden structure with wooden walls and thatched roof. Bamboo and coconut wood are frequently used for the non-load bearing elements. The roofs are thatched with leaves of sugar or coconut palms but many of them are nowadays replaced by zinc roofs. The dramatically inclined roofs make the vast amounts of tropical rainwater to run swiftly and safely away, and the overhanging 
eaves shade the windows and protect them from the driving rain. The wooden structure instead of nails use wedges, pegs and lashing techniques for the joints. The substructure is stabilized by a system of beams into the piles by which construct a secured place for the livestock during the night.

The wall of the house is insignificant in size compared to the roof, whose great weight is supported by piles. The interior of the house is dark, cramped and smoky. A home is a place for sleeping in the night, as most of the day the activities of the inhabitants are outdoors. Some parts of the house are not structurally essential but are decorative elements. Rafters, pillars and roof friezes are frequently carved or painted with symbolic figures and spirits imagery.

Batak Toba architecture makes us realized and directs our consciousness back to the comprehensive world of nature and toward our own sense of self and being. A building may simply be there at a place, yet it is impossible to imagine the place without the existence of the building. Buildings can only be accepted if they have the ability to appeal to people's emotions and minds in various ways. The architecture of buildings is in fact to create embodied and lived existence that structure and concretize man's being in the world. It is the buildings that enable us to structure, to understand and to remember the shapeless flow of reality, and ultimately to recognize and remember who we are. Vernacular architecture enables us to perceive and understand the dialectics of permanence and change and to place ourselves in the world. In its way of representing and structuring power and natural forces, vernacular architecture is engaged with existential questions. Only the imaginative actions of architecture that make possible to figure out how we come into the place we occupy and what prospects in the future we have. Imaginative buildings express the nature as an inspiration for creative works and not as something to be replaced, and they engage our senses by means of ingenious inscriptions of many layered meanings no one can grasp at a glance.

\section{Materials and Method}

\subsection{Literature Review}

This paper is written in the attempt to understand and reveal the way in which vernacular tradition respond and react to environmental setting of the settlements. Buildings and settlements are seen as artifacts that convey creative processes through which people interpret their environment and experience the overwhelming power of the nature. The research undertaken is encouraged by the writing of Marcel Vellinga and Lindsay Asquith who edited the book Vernacular Architecture in the Twenty-First Century, which mark that studying vernacular architecture will enlighten the general principles and mechanisms of building design that are more relevant to a problem oriented system. In this approach vernacular design is thought of as a model to study phenomena in another, such as future design of a building that is environmental friendly. Vernacular design will as well lead to the identification of visual characters that best exemplify the relationship between human being and environment. It is assumed that such characters are constant though differently expressed in different contexts and communities. There are some discussions and conceptual framework written by Amos Rapoport, anyhow there is indeed still much research needs to be undertaken to provide important lessons from vernacular design.

Marcel Vellinga and Lindsay Asquith has pointed out that Ronald Lewcock argues for the existence of "mental models" or "generative concepts" that explain similarities that 
are found between architectural expressions in many parts of the region or between architectures of different time periods. Those concepts are developed in the mind of people using emotional connections of memory, particularly that are simple and strong. Out of this memory the basis of architectural or artistic expressions is formed. The capacity of a human to establish connections between ideas, emotions, forms and spaces gives rise architectural ideas that may be notified as archetypes which may be in common to all mankind or to a specific society. Lewcock identifies generative concepts in vernacular architecture are among others: the hearth, the courtyard, and the anthropomorphic analogy, that are likely to persist although tradition do change through new technology. Innovation and precedent are always dynamically combined which causes continuous changes in architecture, yet the underlying generative concept remain the same. Studying such concepts and the impact on building design is indeed a promising research for the future architecture.

The philosopher Heidegger is the one who initially introduced the concept of building and dwelling as an intimately bound up mode of thinking. The activity of building and dwelling is being related through people's involvement with the place in the attempt to make sense of a place. He claimed that dwelling is a peaceful accommodation between individuals and the world, between people and their surroundings, whereas building is a mode that involves cultivating and nurturing. To Heidegger building and dwelling are understood as one and the same activity which is vitally connected with human presence in the world. Building and dwelling are interwoven with earth - sky - divinities - mortals. For Heidegger, the earth situates the humans and to be on the earth is also to be at one with the sky, whereas the sky enveloped human existence. Earth and sky remains interlocked as ever-present companions. Earth, sky and divinities shaped daily life, and in the shadow of mortality they make possible of celebrating existence, rituals and rites of passage. Heidegger hereafter claimed that dwelling contains a proper sense of order to resist the ever extending of human control into the world.

Christian Norberg-Schulz in his book The concept of dwelling describes dwelling as having 3 meanings: 1) to meet others for exchange of products, ideas and feelings; 2 ) to come to an agreement with others; 3 ) to be oneself. In this understanding, to dwell is to build a relationship between a man and the nature, as well as to identify the being of a man in an open and free land. Everyone needs to know the place one belongs to in order to be able to experience one's existence as meaningful. Everybody determines the place by the ground on which one stands and by the sky above the heads. To know a place and to belong to a place will be realized when the place discloses itself to the man. A place becomes meaningful when it has conditioned one's being and personality. Life becomes "right" and "true" because of the sound relationships, and the existence becomes what it "is". The place, therefore, unites a group of people, gives them a common identity and a basis for the community. Norberg-Schulz stated that a house has to do with the earth and the sky, and a social meaning. Houses belong together like members of family. When it is right, there is sympathy between houses.

When people identify with a place, people dedicate themselves to a way of being in the world. A house is understood as an object that represents the totality of earth and sky, and the architecture of the house is dedicated to make that understanding to be a concrete fact. Hence, a house becomes an object of human identification because it makes the world stand forth as it is. The identity is also depicted with the atmosphere which maintains the existence through environmental character such as climatic and seasonal changes. People undertake actions based on environmental image because it 
gives a sense of emotional security, as it is noted by Kevin Lynch in his book The Image of The City. Direction is another thing that makes people finds the way of being in the world. People orientate with in and in relation to environmental images to attain unity with the place they constitute. Houses because of its built form have to possess a spatial order which is related to the nature as well as to the human actions themselves. The house and settlements visualize the spatial organization of the situation and its context.

Referring further to Norberg-Schulz, the purpose of architecture is to accommodate a human being to dwell in his world so that he may stay poised in place and time. To be able to establish a meaningful relationship with a given environment, it is necessary that architecture goes beyond neither stylistic elements nor abstraction concept in its effort to manifest the dwelling concept. The archetypes are therefore the essences of architecture. They will come into sight in a variety of contexts and in different interpretations. Architecture must be rethinking as a figurative art in built form and organized space. Creative architecture will emerge when these archetypes are adapted, modified and explored to place and time. Michael Graves, a representative of the post modernist architects, underlined this stance in the publication of his projects in 1982 that architecture should reestablish its associative character to nature and its anthropomorphic or figurative meaning.

\subsection{Methodology}

The research is focused in discovering the physical manifestation of man-nature relationship in vernacular buildings and settlements, in which it is assumed to be the essence of local knowledge and wisdom. The research is intended to discover the underlying framework and ordering system of building mass, roof form, and spatial layout in articulating the environmental phenomena and the dependency of man to nature, by which its appropriateness in accommodating domestic activity is scrutinized to the thought of architectural ideas.

This paper is preceded by field surveys in late 2010 and early 2011 to Batak Toba settlements in Samosir Island of Lake Toba, North Sumatra, which have been selected because of the graciously expressed admiration to the ancestor and predecessor. Samples of houses are singled out from vernacular settlements in the neighbourhood of Tomok, the nearest port city from mainland Sumatra. Further on typology of houses are selected based on geographical and societal aspects, hence three (3) different location and physical setting of settlements (the lake, the hill and the middle terrain context) are chosen to study consistency of spiritual thought that predominates any other ideas. Samples of research must be currently inhabited and well kept as a dwelling unit. The building and its architecture is rather original and does not undergo substantial physical changes.

The comparison of those houses applies the anthropomorphic paradigm - head body - foot - of vernacular architecture, in which embodiment of tangible and intangible content in architectural ideas will be scrutinized. Human analogies in vernacular architecture use the human body as a metaphor for comparable spatial uses, structural, decorative and symbolic forms. Just as a human has a soul, so does a house. Therefore, the research question is what kind of invisible power dimension is being made visible through the architecture of the house, by which fascinating roof form and style in Batak House might be accounted for.

The field survey do observe the uses of space inside and outside the building, record photographically the physical existence of the building, and interview the inhabitants on 
their respect to the ancestor and predecessor. The data collected on field are then carried out along with literary study of ethnographical and anthropological research on Batak Architecture and Batak People, to discern deeper insight of intangible dimension of cultural artefact. Further literature study of thesis work of post graduate students at the Department of Architecture ITB has also been undertaken to round the process of analysis. To the purpose of comprehensive discernment of Batak culture, other traditional houses in Batak culture such as Batak Karo and Batak Simalungun have also been studied.

\section{Results and Discussions}

\begin{tabular}{|c|c|c|c|}
\hline & Huta Siallagan & Lumban Simarmata & Janji Martahan \\
\hline & $\begin{array}{l}\text { Row of houses are set up within the } \\
\text { stone wall boundaries }\end{array}$ & $\begin{array}{l}\text { Pet } \\
\text { Row of houses are laid out directly } \\
\text { to the mountain range }\end{array}$ & $\begin{array}{l}\text { Row of houses are laid out in the } \\
\text { middle of cultivated land }\end{array}$ \\
\hline & $\begin{array}{l}\text { The roof form evokes a mountain's } \\
\text { ridge. }\end{array}$ & $\begin{array}{l}\text { The roof form imitates the ridge of } \\
\text { a mountain }\end{array}$ & $\begin{array}{l}\text { Le } \\
\text { The roof form corresponds to the } \\
\text { mountain's ridge }\end{array}$ \\
\hline & Friendly gesture of the house & $\begin{array}{l}\text { Lat } \\
\text { Standing figure of the house }\end{array}$ & Impressive figure of the house \\
\hline
\end{tabular}




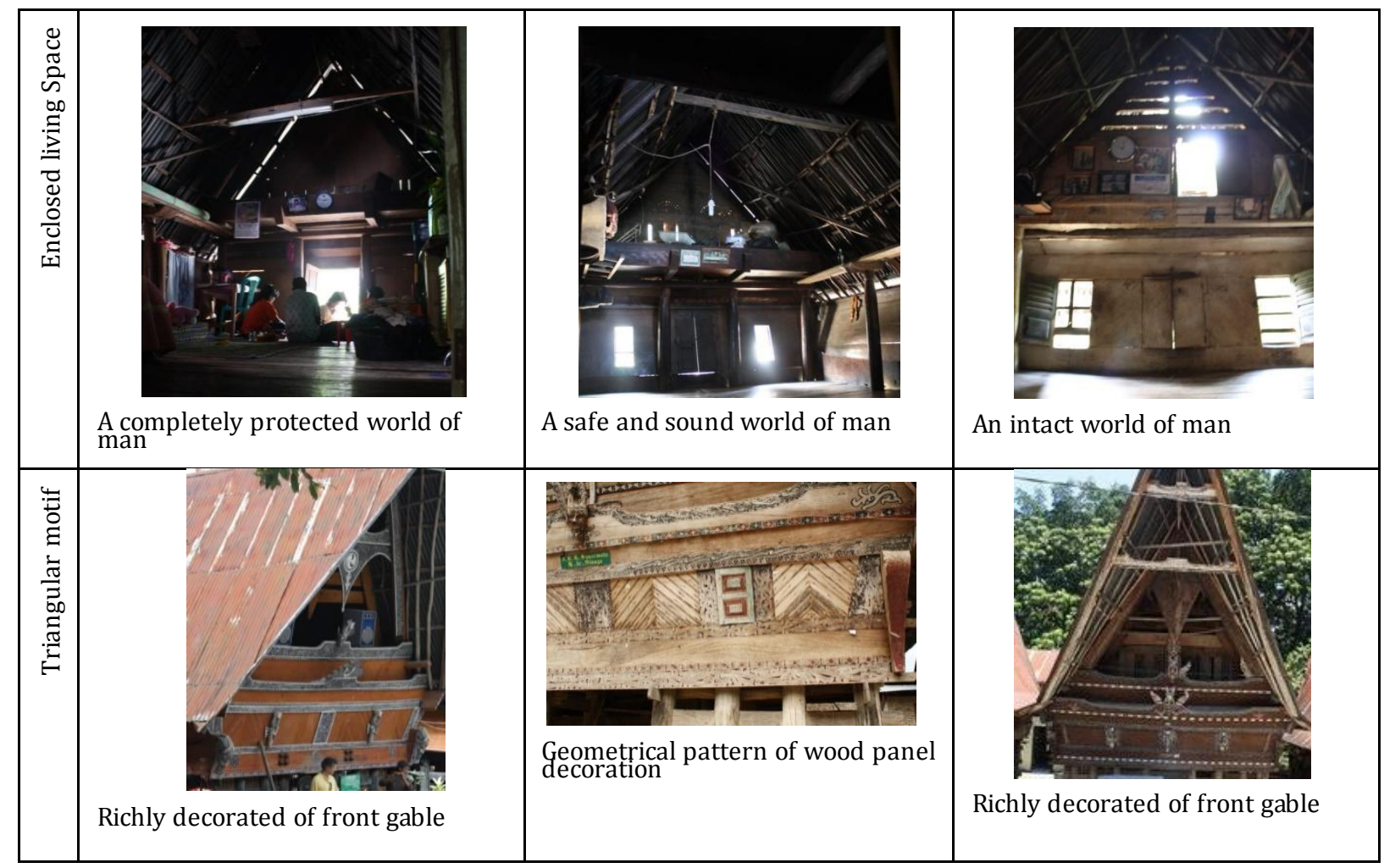

Figure 1: Comparison of Three Batak Toba Villages

Source: (Author, 2011)

\subsection{General description}

The three case studies illustrate the manifestation of a village as the center of the world. Each village consists of no more than ten houses built close together and it is built on a favourable location. The Huta Siallagan is being fortified by stone walls but the other two villages have no physical boundaries. Houses in those three villages stand side by side with the front gable facing the open space and to the north direction. Houses are located along the axis of Mountain-Lake direction with the front gable is directed toward the mountain.

Huta Siallagan is an original village which is founded by the clan Siallagan who owned the agriculture land in the surrounding of the village. The inhabitants of the Huta are exclusively descendants of the clan Siallagan and they keep the original settlement for the benefits of touristic attraction. All of the inhabitants are involved in the activities related to tourism that becomes their currently earnings. Lumban Simarmata is a new village founded by the chief of clan Simarmata outside the original village yet within their territorial land for the new descendants. The inhabitants are descendants of the clan Simarmata and agricultural production are even now their major income. Janji Martahan is a new village occupied by descendant of several clans within the territorial of land belongs to the Martahan family. The inhabitants build their own houses but they have no property right of the land. The village is rather abandoned since most of the inhabitants move outside the village for office work in the city.

Each house in those three villages inhabited by a single family and the interior of the house is not divided by partition walls. The enclosed space is dark, and light enters into the house through small windows on each side. The house is largely used for sleeping 
since most of the time the activities of inhabitants are undertaken outdoors. An attic space is provided by a flat wooden ceiling over the front space where heirlooms are stored. The walls that constitute the middle section of the house are made of wood, lean outwards and provide additional stability to the structure.

The upper section of the house in those three villages similarly dominates the silhouette of the building. The large steeply-pitched roof has front gable that extends further than the rear gable represents the cultural values of the younger generation who gets the better of his predecessor. The longitudinal profile of the roof simulates the ridge of a mountain. Accordingly the front gable is finely carved and painted in geometric motifs compared to the rear gable which has no decoration and very plain.

\section{2}

\section{Archetype of Living Space}

Batak houses are self built by the owner with the help of the family, neighbours or builders in the community. The structure of the house is made predominantly of local materials which fit well with local climate and ways of life of the inhabitants. The building system is easy to learn, to understand and to be experienced unconsciously. The natural environment sets the stakes for Batak people and they learn from the environment. To settle in the wilderness means to delimit a place. The Batak settlements become the point of arrival and the center where people are invited to dwell. It represents the comprehensive world. The farm and the village are related to the immediate surroundings: the cultivated land, the mountain, and the lake.

Batak Toba people respect and take care of the given place by interpreting the site and transforming into a human place in relation to natural features: the lake and the mountain. The design of a house responds the built environment and its artifacts. The house belongs to the nature and blends in the environment like a rock or a tree. People seek to express the house as altering the natural into the artificial -the man-made world-. Houses become things of beauty on the natural landscape. To build a house and settlements is to shape the environment that makes life go on and creates signature of people's presence. The architecture of the house hereafter becomes the ability of the people to alter the climate, to shape the environment, to select right materials, by which it claims wilderness as human. The architecture is to make the world better, to secure a place, and to control wilderness into a splendid artifact. People's action is transforming the pragmatic needs into the aesthetic expressions. People seek its conquest in altering the natural into the artificial through processes that smooth the rough and brighten the dull.

Huta Siallagan, Lumban Simarmata and Janji Martahan represents Batak Toba settlements in a city, hill and middle terrain context, yet all of them orientate houses to face the mountain and back of the house at the direction to the lake. Batak Toba houses comparable to any vernacular houses value higher place in natural world such as mountain a preferable place, given that it gives the sense of being closer to heaven or sky. The lake that reflects the sky and blend with it reveals the sense of place which comprises the height of the sky and the depth of the earth. The sky and the earth are categories commonly used to make people see the basic order of things (NorbergSchulz, 1985:18).

The architecture of buildings in the settlements is then created to reveal and emphasize natural qualities that are already present. The architecture becomes a process of visualization of the dominance of mountain and lake, of sky and earth. The roof forms of the buildings may give emphasis to a peak or ridge of mountains. The 
building mass may form an artificial solid center of the earth or a point of arrest on earth or establishment of a relationship between earth and sky. The house brings the earth as an inhabited place to the people and at the same time a place under the expanse of the sky, by which the totality of sky-earth might be experienced. A Batak house is erected as a single entity and highly visible artifact which rises from the ground towards the sky.

The gigantic roof has no internal trusses by which it creates a large interior space underneath. The roof is steeply pitched and saddleback shaped with projecting triangular pattern of gables which is richly decorated with carved and painted motifs of suns, stars, cockerels and geometric motifs in red, white and black. The front gable extends much further out and higher than the rear gable. The front gable is also highly decorated whereas the rear gable is made plain. Light is admitted to the inside space through this triangular decoration and small windows on each side of the house. The house is not designated as a comfortable interior space since most of the day living activities are outdoor. The size of the interior space is surmounted by the magnificent size of the roof.

\subsection{Anthropomorphic artifact}

A Batak Toba house is an object of human identification because it embodies existential meanings of its inhabitants and the staying between the earth and the sky. The earth is alive with active forces and people display respect and awe to those. The world is created by God in three manifestations: one is governing the upper world (God's place), one is governing the middle world (place for the human being) and one in the underworld (the place of demon and spirit). The house respectively is divided in three sections: the lower part for the storage of wood and animals which symbolize the foot, the middle part as the house of the human being which symbolize the body, the attic constituting the biggest part of the house, as the upper world for the God or ancestors which

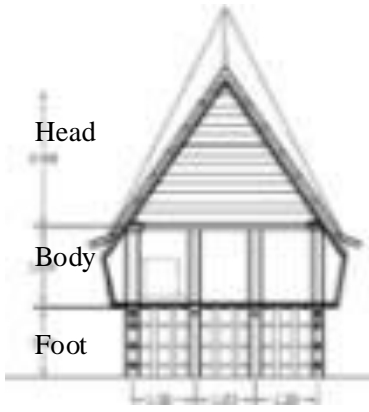

Figure 2: Three Sections of the House

Source: (Author, 2011) symbolize the head. Batak Toba people believe that their ancestors are from Sianjur Mulamula at the foot of Pusuk Buhit volcano on the western shore of Lake Toba. They regard the souls of the ancestors may influence the lives of the descendants long after the death by which they play a role in the lives and destines of the children and grandchildren.

The house unfolds the human position in nature and the distribution of power among people. The ordering system of three sections is parallel to the three societal values of 1) respect to the family of the mother, 2) friendly to the family of the sister and 3 ) tolerant to the family clan. During ritual procession the three systems is exercised in that everybody knows his position and his place in the ceremony. The manifestation of three sections in the house associates to the three aspects of life that relate one to another. In kinship system there are 3 different parties to be respected by the member of a family. The first one is the family of the wife giver - the family his wife comes from, the second is the family of the wife taker - the family which the daughter of his own family marry into, and the third is one's own family clan. A married Batak man has close social relationships with his own family and two other family groups. The root of Batak culture is Dalihan Na Tolu, meaning the three hearthstones built up out of 3 stones. The 
decorations on the façade of the house consist of three-dimensional carvings of figural representations, relief and paintings with three natural colours: white, red, black. These three colour represent the three spheres of the cosmos, the three hearthstones and the three supports of the family system - three kinship groups which are of prime importance to Batak people. The three colour are red from a red earth, black from the charcoal and white from lime

The house consists of only one enclosed space with no partition wall in between. The roof section has an airy framing structure of boards with a carved pattern in front of the inner gable. Batak Toba people protect the family life inside their houses not only from view, but also from evil spirits. The entrance way of the settlements force people to enter at an angle and keeps the spirits out. The house is characterized by the massiveness of its construction by which is advantageous as a defence mechanism against the enemy in times war between villages. When doors and windows are closed and the stair is pulled up, the house is not accessible at all. Arrangement of houses involves concepts of relationship with the environment as well as requirements of security and family clan.

\section{Conclusion}

The arrangement and design of Batak Toba houses involve the concept of location and orientation. The arrangement of houses in a settlement is an expression of the relationship of man with nature. The Batak Toba people have figurative imagination in which they orientate themselves on nature and surrounding landscape. To them the environment is full of meaningful reference points and they use the contextual relationship of mountain-lake as a generative force for innovative design of buildings. The building mass of a house has been highly abstracted to offer a sustaining sense of security against the uncertainties of environments in which change is inevitable but directions are perceived. There is nevertheless no difference among the three Batak Toba settlements in interpreting their natural surroundings.

A Batak house always embodies what it means to be human, in that parts of the house are equated with parts of the human body, and as the middle distance between the earth and sky. The figurative imagination is made to be perceived and looked at. The Batak people do identify local and natural experiences through unconscious practice. They depend on cooperative interaction with the environment because nature itself is too hard to overcome. It is not just the climate that set the limits of building design, but materials available are modest and tight too. People are forced to be innovative not by individual expression but through identification with the community that resides within them. The architecture of the house and the organization of the settlements are the work of the people and the user.

The study of Batak Toba architecture reveals the understanding of how people create architecture which is not based on physical aspect of domestic living, but on its suitability for human needs that are both physical and spiritual by using materials available to them. To the Batak people architecture has the aim of making the intangible perceptible. Within three settlements in Samosir Island house form tends to be persistent in time and space in which conformity and continuity reflect the cultural coherence and deep rooted tradition of the people. 


\section{Acknowledgement}

This paper is written based on previous research undertaken by the author, which is funded by The Ministry of Education Republic of Indonesia under the project scheme of

National Strategic Research DIPA DIKTI 2010, Contract No. 548/SP2H/PP/DP2M/VII/2010

\section{References}

Asquith, Lindsay, Vellinga, Marcel (ed). (2006). Vernacular Architecture in the TwentyFirst Century. New York: Taylor \& Francis

Bonatz, D., Miksic, J., Neidel, J. D., \& Tjoa-Bonatz, M. L. (2009). From Distant Tales Archeology and Ethnohistory in the Highland of Sumatra. Cambridge: Scholars Publishing.

Building Research Institute (1973). Tradisional Buildings of Indonesia Vol. I Batak Toba. Ministry of Public Work and Electrical Power

Building Research Institute (1973). Tradisional Buildings of Indonesia Vol. II Batak Karo. Ministry of Public Work and Electrical Power

Building Research Institute (1973). Tradisional Buildings of Indonesia Vol. III Batak Simalungun and Batak Mandailing. Ministry of Public Work and Electrical Power

Crouch, Dora P. \& Johnson June G. (2001). Traditions in Architecture. Africa, America, Asia and Oceania. Oxford: Oxford University Press.

Dawson, Barry. (1994). The Traditional Architecture of Indonesia. London: Thames and Hudson Ltd

Departemen Pendidikan dan Kebudayaan. (1997). Arsitektur Tradisional Daerah Sumatra Utara. Jakarta:Departemen Pendidikan dan Kebudayaan Republik Indonesia

Domenig, Gaudenz. (2004). Indonesian Houses Vol. I. Singapore: Singapore University Press

Noble, Allen G. (2009). Traditional Buildings. New York: IB Tauris \& Co. Ltd.

Norberg-Schulz, Christian. (1985). The Concept of Dwelling. On The Way to Figurative Architecture. New York: Rizzoli International Publications, Inc.

Papanek, Victor. (1995). The Green Imperative. Ecology and Ethics in Design and Architecture. Singapore: Thames and Hudson.

Pusat Penelitian dan Pengembangan Permukiman. (2010). Laporan Kegiatan Pengkajian Rumah Tradisional Etnis Batak di Propinsi Sumatera Utara. Binjai: Loka Teknologi Permukiman Medan

Schefold, Reimar, Nas, Peter JM, Domenig, Gaudenz, Wessing, Robert (eds). (2008). Indonesian Houses. Leiden: KITLV Press

Sharr, Adam (2007). Heidegger for Architects. New York: Routledge

Sherman, D. G. (1990). Rice, Rupee, and Ritual. California: Stanford University Press.

Sibeth, Achim. (1991). The Batak, People of the Island of Sumatra. London: Thames and Hudson Ltd. 